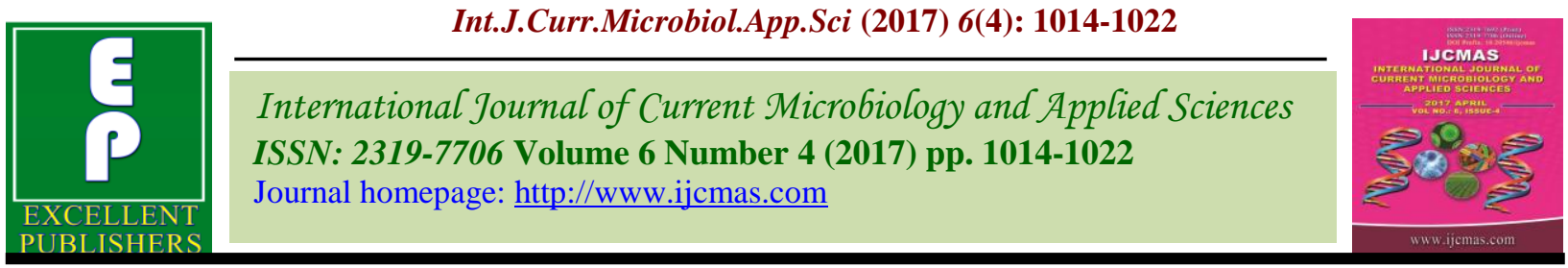

Original Research Article

https://doi.org/10.20546/ijcmas.2017.604.126

\title{
Luteimonas aestuarii SA13A as a Novel Chromium Reducing Strain isolated from Tannery Effluent
}

\author{
Ankita* and Baljeet Singh Saharan \\ Department of Microbiology, Kurukshetra University Kurukshetra-1136119 (Haryana), India \\ *Corresponding author
}

A B S T R A C T

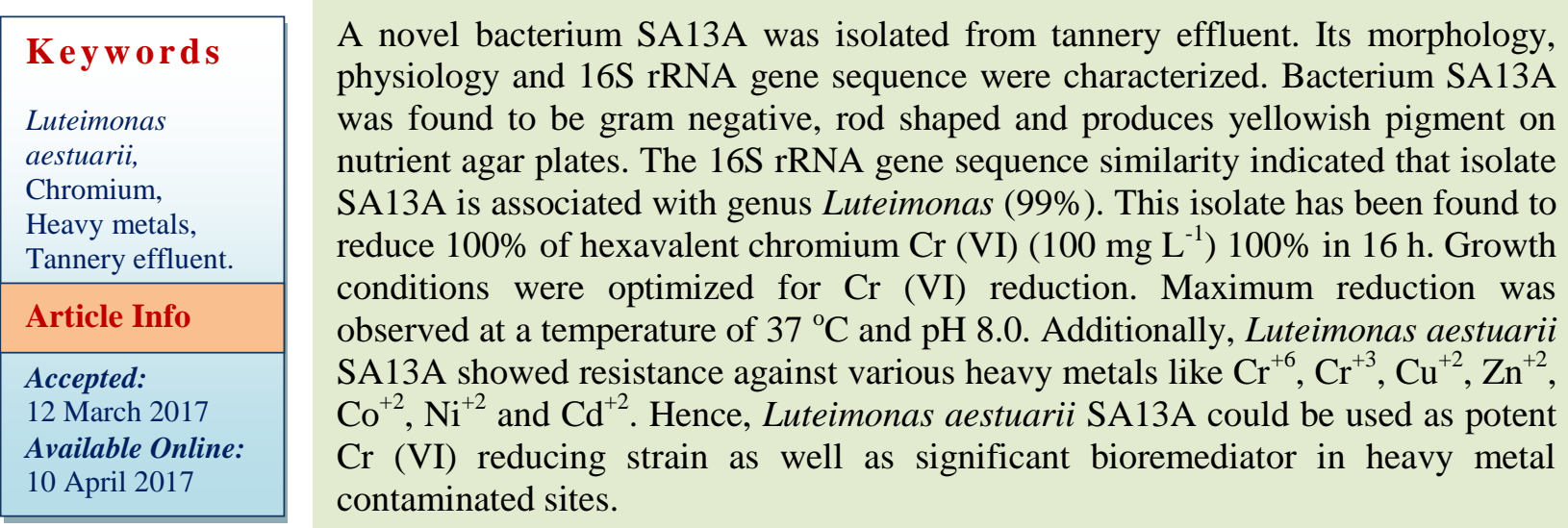

\section{Introduction}

Industrialization is hallmark of civilization but environmental degradation happening due to this is becoming a matter of great concern. Industrial emissions unfavorably affect the environment, leading to large-scale worldwide destruction of agricultural land and water bodies (Poopal et al., 2009; Alam et al., 2012). Various toxic substances released during industrial processes accumulate in the environment and food chains, thereby upsetting ecosystems and biological processes in many organisms. Chromium $(\mathrm{Cr})$ is one of the heavy metal that is employed widely in numerous industrial processes, including chrome leather tanning, chrome plating, ceramics, dyes, paints and pigments manufacturing, textile processing and metal finishing (Thacker et al., 2006; Cheung and Gu, 2007; Desai et al., 2008; Masood and Malik, 2011). Leather processing industry is one of the major industries utilizing chromium in the form of chrome liquor or chrome powder. Residual chromium is thus discharged in the form of solid as well as liquid effluent into land and water bodies.

Chromium exists in various oxidation states with valencies ranging from -2 to +6 but the most persistent forms are hexavalent $\left(\mathrm{Cr}^{6+}\right)$ and trivalent $\left(\mathrm{Cr}^{3+}\right)$ forms. Hexavalent chromium is the most toxic form, mainly available as oxyanions, whereas trivalent chromium which is hundred-fold less toxic, less soluble, less mobile and is mostly found 
as oxides, hydroxides or sulfates (Cervantes $e t$ al., 2001; Patra et al., 2010). Hexavalent chromium is a strong oxidizing agent, mutagen and teratogen (Cheung and $\mathrm{Gu}$, 2007; Costa and Klein, 2006). Its oxyanionic form $\left(\mathrm{CrO}_{4}{ }^{2-}\right)$ is analogous in structure to sulfate and phosphate ions which readily permeates through bacterial and eukaryotic cells resulting in intracellular reduction finally leading to chromate-induced toxicity (Cheung and Gu, 2007; Patra et al., 2010; Asatiani et al., 2004). The presence of chromate in the environment inhibits most microorganisms, but it also promotes the selection of metal resistant bacteria (Alam et al., 2012; Mondaca et al., 1998).

In Kanpur, about 400 leather processing industries at Jajmau, discharge both liquid as well as solid wastes into canals and rivers with residual chromium. This causes chromium contamination not only in the water bodies but also accumulates in aquatic organisms, lands, vegetables, farm products and crops thereby posing a great threat to environment and human health. The most direct and severe effect comes out with leather-cut wastes, which are conventionally being processed into feed ingredient (as a protein source). This chromium content thus acts as major source for its migration into the food chain.

Chromium does not degrade completely but can be transformed or removed either through adsorption/accumulation or by physic chemical treatments. Large amount of chemicals as well as energy is required during these processes, making them unsuitable for execution on a large scale (Camargo et al., 2003). Chromium resistant bacteria offer an economical and eco-friendly alternative method for chromate detoxification along with its bioremediation (Patra et al., 2010; Pal et al., 2005). Chromium reduction takes place under both aerobic as well as anaerobic conditions. Numerous bacteria have been reported for their ability in reducing/transforming $\mathrm{Cr}^{6+}$ to $\mathrm{Cr}^{3+}$ e.g. Bacillus sp., Escherichia coli, Enterobacter cloacae, Pseudomonas fluorescens, Providencia sp., Exiguobacterium sp. etc. (Bopp et al., 1983; Wang et al., 1989; Shen and Wang, 1993; Okeke et al., 2008; Yang et al., 2009).

The present study aimed to isolate the chromate resistant and chromate-reducing bacteria from the chromium landfill where the hexavalent chromium level is quite high, analyze the bacterial chromate reduction efficiency and determine the preferable conditions for bacterial chromate reduction, to provide useful knowledge for the bioremediation of chromate polluted areas.

\section{Materials and Methods}

\section{Isolation of bacterial strains and cultural conditions}

Samples were collected from outlet of tannery effluent treatment plant situated at Jajmau (Kanpur, Uttar Pradesh) and further processed. Isolation of the bacterial culture was done using enrichment culture technique. Luria Bertani (LB) broth was amended with $10 \mathrm{mg} \mathrm{L}^{-1}$ of $\mathrm{K}_{2} \mathrm{Cr}_{2} \mathrm{O}_{7}$ and soil suspension $(10 \%, \mathrm{w} / \mathrm{v})$ was prepared in sterile distilled water, which was incubated at $37{ }^{\circ} \mathrm{C}$ for $24 \mathrm{~h}$. After $24 \mathrm{~h}$ enriched bacterial strains were isolated by plating on LB agar plates amended with 10 to $100 \mathrm{mg} \mathrm{L}^{-1}$ of $\mathrm{K}_{2} \mathrm{Cr}_{2} \mathrm{O}_{7}$. Only one isolate (SA13A) was able to grow upto conc. of $100 \mathrm{mg} \mathrm{L}^{-1}$ of hexavalent chromium $(\mathrm{Cr}$ (VI)), and was used in further studies.

\section{Identification of isolated strain}

Identification was done by $16 \mathrm{~S}$ rRNA analysis using universal primers. The sequences of the primers used for the 
amplification $\quad$ were: $\quad 16 \mathrm{SF} \quad\left(5^{\prime}-\right.$ AGAGTTTGATCCTGGCTCAG-3') and 16SR (3'-ACGGCTACCTTGTTACGACTT5').

Sequence was analyzed at NCBI server (http://www.ncbi.nlm.nih.gov.) using BLAST (N) program. Phylogenetic tree was constructed by the UPGMA method using the MEGA 5 (Molecular Evolutionary Genetics Analysis) software (v. 5.05) (Tamura et al., 2011). The final sequence was deposited at GenBank.

\section{Evaluation of metal tolerance}

The minimum inhibitory concentration (MIC) was determined in LB broth amended with heavy metal salts such as $\mathrm{CdCl}_{2}, \mathrm{CuSO}_{4}$, $\mathrm{CoCl}_{2}, \mathrm{CrCl}_{3} \cdot 6 \mathrm{H}_{2} \mathrm{O}, \quad \mathrm{K}_{2} \mathrm{Cr}_{2} \mathrm{O}_{7}, \mathrm{NiCl}_{2}$ and $\mathrm{ZnCl}_{2}$ at varying concentrations from 50 to $3000 \mathrm{mg} \mathrm{L}^{-1}$ (Aleem et al., 2003; Ansari et al., 2008). The minimum concentration of the metal inhibiting complete growth was taken as the MIC.

\section{Time course of growth and chromium reduction}

Growth curve of the bacterial isolate SA13A was determined in LB medium amended with Cr (VI) (100 mg L ${ }^{-1}$ ) and without chromium (control). Media was inoculated with $1 \%$ exponential phase bacterial culture and incubated at $37{ }^{\circ} \mathrm{C}$ with shaking $(120 \mathrm{rpm})$. An aliquot of culture was taken out in sterilized tube at regular intervals $(2 \mathrm{~h})$ and absorbance was measured at $600 \mathrm{~nm}$.

Withdrawn samples were centrifuged $(10,000$ g; 15 min) and supernatant was used to determine residual $\mathrm{Cr}$ (VI) concentration using S-diphenylcarbazide (DPC) method (Ilias et al., 2011). The absorbance of the color produced was measured at $540 \mathrm{~nm}$ using UV-Visible spectrophotometer (Systronics, 2202).

\section{$\mathrm{Cr}$ (VI) reduction at optimized cultural conditions}

To characterize the $\mathrm{Cr}$ (VI) reduction efficiency, the effect of temperature and $\mathrm{pH}$ on growth and $\mathrm{Cr}$ (VI) reduction was investigated using LB medium containing 100 $\mathrm{mg} \mathrm{L}^{-1}$ of $\mathrm{Cr}$ (VI) (as $\mathrm{K}_{2} \mathrm{Cr}_{2} \mathrm{O}_{7}$ ). Media were inoculated with $25 \mu \mathrm{l}$ of overnight bacterial culture. Chromium reduction and growth was studied at various incubation temperatures (20 to $45{ }^{\circ} \mathrm{C}$ ). For the effect of $\mathrm{pH}$, sterilized culture medium was adjusted to $\mathrm{pH}$ ranging from 6.0 to 10.0 and incubated at $37{ }^{\circ} \mathrm{C}$. Growth was measured after $24 \mathrm{~h}$ of incubation by taking absorbance at $600 \mathrm{~nm}$. The culture was centrifuged $(10,000 \mathrm{~g} ; 15 \mathrm{~min})$ and the supernatant was used to determine the residual $\mathrm{Cr}$ (VI) concentration. In order to examine any abiotic $\mathrm{Cr}$ (VI) reduction, cellfree controls were used for each $\mathrm{Cr}$ (VI) reduction assay.

\section{Statistical Analysis}

All the experiments were performed in triplicates. Data are presented as mean \pm SD (Standard deviation).

\section{Results and Discussion}

\section{Isolation of bacterial strain and cultural conditions}

Effluent released from tanneries contains high concentration of chromium and other heavy metals. This heavy metal contamination is responsible for shifts in microbial communities along with the emergence of elevated metal tolerant bacteria (Masood and Malik, 2011; Ansari et al., 2008; Stepanauskas et al., 2005). In search for chromium-resistant microorganisms, a total of $8 \mathrm{Cr}$ resistant bacteria were isolated on plates amended with 10 to $100 \mathrm{mg} \mathrm{L}^{-1}$ of $\mathrm{Cr}$ (VI) as $\mathrm{K}_{2} \mathrm{Cr}_{2} \mathrm{O}_{7}$, Out of which only one strain 
(SA13A) was able to tolerate Cr (VI) (Conc. $100 \mathrm{mg} \mathrm{L}^{-1}$ ). All further studies were done on this strain.

\section{Identification of isolated strain}

Amplified DNA fragments were sequenced using Sanger Dideoxy method (Hattori et al., 1986). Forward and reverse sequences of the isolate were joined using DNA Baser (v 3.5.3) which identified the isolate as Luteimonas aestuarii. The 16S rRNA gene sequence obtained from the isolate was compared with other bacterial sequences using NCBI mega BLAST (http://blast.ncbi.nlm.nih.gov/ Blast.cgi) for their pair wise identities. Isolate showed 99\% 16S rRNA sequence homology to Luteimonas sp. at NCBI database. The $16 \mathrm{~S}$ rRNA sequence of the isolated bacterium was submitted in the Genbank (NCBI) with an accession number KC540915. Further, consensus sequences were aligned and compared with the available database in NCBI. The phylogenetic tree was constructed using MEGA 5.05 software to determine evolutionary relationships of the isolate. The phylogenetic relationship of the SA13A isolate showed close relatedness with Luteimonas aestuarii strain B9 (Figure 1). According to scientific literature, this species of bacteria has never been reported as chromium resistant strain.

\section{Evaluation of metal tolerance}

Cr (VI) bearing wastewaters usually contain many other heavy metal cations. Therefore in addition to $\mathrm{Cr}$ (VI), resistance to various metallic salts was also determined. The bacterial isolate SA13A possessed multiple metal ion resistance. MIC of various heavy metal salts i.e. $\mathrm{CdCl}_{2}, \mathrm{CuSO}_{4}, \mathrm{CoCl}_{2}$, $\mathrm{CrCl}_{3} \cdot 6 \mathrm{H}_{2} \mathrm{O}, \mathrm{K}_{2} \mathrm{Cr}_{2} \mathrm{O}_{7}, \mathrm{NiCl}_{2}$ and $\mathrm{ZnCl}_{2}$ were found to be 200, 800, 400,1500, 3000, 400 and $600 \mathrm{mg} \mathrm{L}^{-1}$ respectively. The degree of inhibition caused by tested metal cations was:
$\mathrm{Cr}^{+6}>\mathrm{Cr}^{+3}>\mathrm{Cu}^{+2}>\mathrm{Zn}^{+2}>\mathrm{Co}^{+2}=\mathrm{Ni}^{+2}>$ $\mathrm{Cd}^{+2}$. SA13A showed maximum tolerance towards $\mathrm{Cr}$ (VI). Similar findings have been suggested by Camargo et al., (2003). Various chromium resistant bacteria have been reported that could tolerate $\mathrm{Cr}$ (VI) up to concentration of $2000 \mathrm{mg} \mathrm{L}^{-1}$ (Ilias et al., 2011). Also, MIC values of chromium resistant bacteria have been compared and it has been found that different isolates exhibited different level of tolerance (Masood and Malik, 2011; Viti et al., 2003) towards various heavy metals. Tolerance towards other heavy metals provides an additional advantage of the bacteria, as it can perform the preferred activity in the presence of metallic ions also.

\section{Time course of growth and chromium reduction}

Time course of growth and $\mathrm{Cr}$ (VI) reduction was investigated in presence of $\mathrm{Cr}$ (VI) (Conc. $100 \mathrm{mg} \mathrm{L}^{-1}$ ) in shake flask culture. Growth curves of the bacterial isolate SA13A with and without $\mathrm{Cr}$ (VI) were plotted (Figure 2) and compared. Cells grew well in the medium containing $100 \mathrm{mg} \mathrm{L}^{-1} \mathrm{Cr}$ (VI), although differences in growth patterns were observed between cells grown in control and those grown in the medium. It has been found that growth of the isolate SA13A is lower in $\mathrm{Cr}$ than the control indicating that $\mathrm{Cr}$ (VI) has toxic effect on the growth of the cells.

$\mathrm{Cr}$ (VI) reduction potential of the isolate SA13A was assessed by DPC method. It was found to be growth associated (Figure 3). Isolate SA13A efficiently reduced $100 \mathrm{mg} \mathrm{L}^{-1}$ of Cr (VI) (38.98 \pm 0.62$) \%,(53.45 \pm 0.76) \%$, $(85.78 \pm 0.54) \%$ and $(99.98 \pm 0.56) \%$ after $06,08,10$ and $16 \mathrm{~h}$ respectively. Ilias et al., (2011) reported complete $\mathrm{Cr}$ (VI) $\left(20 \mathrm{mg} \mathrm{L}^{-1}\right)$ reduction by Staphylococcus aureus and Pediococcus pentosaceus in $6 \mathrm{~h}$ and $24 \mathrm{~h}$ respectively. Similar observations have been 
reported by Masood and Malik (2011) or Bacillus sp. It has been found to involve in $100 \% \mathrm{Cr}$ (VI) (100 $\left.\mathrm{mg} \mathrm{L}^{-1}\right)$ removal within 48 h. Bacillus sphaericus AND303 has been reported to provide $\mathrm{Cr}$ (VI) removal $(72 \%)$ within 24 h (Pal et al., 2005).

\section{Cr (VI) reduction at optimized cultural conditions}

Temperature has noteworthy effect on microbial $\mathrm{Cr}(\mathrm{VI})$ reduction. $\mathrm{Cr}(\mathrm{VI})$ reduction was evaluated at various range of temperature $\left(20{ }^{\circ} \mathrm{C}\right.$ to $\left.45{ }^{\circ} \mathrm{C}\right)$ and it has been found to be growth associated. The isolate SA13A significantly reduced $\mathrm{Cr}(\mathrm{VI})\left(100 \mathrm{mg} \mathrm{L}^{-1}\right)$ at all temperatures but the optimum reduction $(98.98 \% \pm 0.29)$ was observed at $37{ }^{\circ} \mathrm{C}$. Moreover, it has been found that $\mathrm{Cr}$ (VI) reduction increased with increase of temperature up to $37{ }^{\circ} \mathrm{C}$ and thereafter decreased above $40{ }^{\circ} \mathrm{C}$ (Figure 4). Similar reports have been given by Ilias et al. (2011) for Staphylococcus aureus and Pediococcus pentosaceus. Maximum $\mathrm{Cr}$ (VI) reduction was observed between $35{ }^{\circ} \mathrm{C}$ and $40{ }^{\circ} \mathrm{C}$ for both the isolates. Moreover, $\mathrm{Cr}$ (VI) reduction by Bacillus sp. strain FM1 was also found to be growth associated and optimum reduction $(100 \%)$ was at $37{ }^{\circ} \mathrm{C}$ (Masood and Malik, 2011). Similarly, maximum Cr (VI) reduction by Ochrobactrium intermedium SDCr-5 was reported at $37{ }^{\circ} \mathrm{C}$ (Sultan et al., 2007). As seen in figure 4 , the bacterial isolate SA13A possessed the capability of growing and reducing more than $95 \% \mathrm{Cr}$ (VI) (Conc. 100 $\left.\mathrm{mg} \mathrm{L}^{-1}\right)$ over a wide range of $\mathrm{pH}$ (6.0 to 8.0) but the optimal $\mathrm{Cr}$ (VI) reduction $(100 \% \pm$ 1.09) was observed at $\mathrm{pH}$ 8.0. The optimal $\mathrm{pH}$ for $\mathrm{Cr}$ (VI) reduction by various bacterial isolates has been reported between 7.0 and 8.0 (Masood and Malik, 2011; Ilias et al., 2011).

Fig.1 Phylogenetic relatedness of Luteimonas aestuarii SA13A based on $16 \mathrm{~S}$ rRNA gene sequence

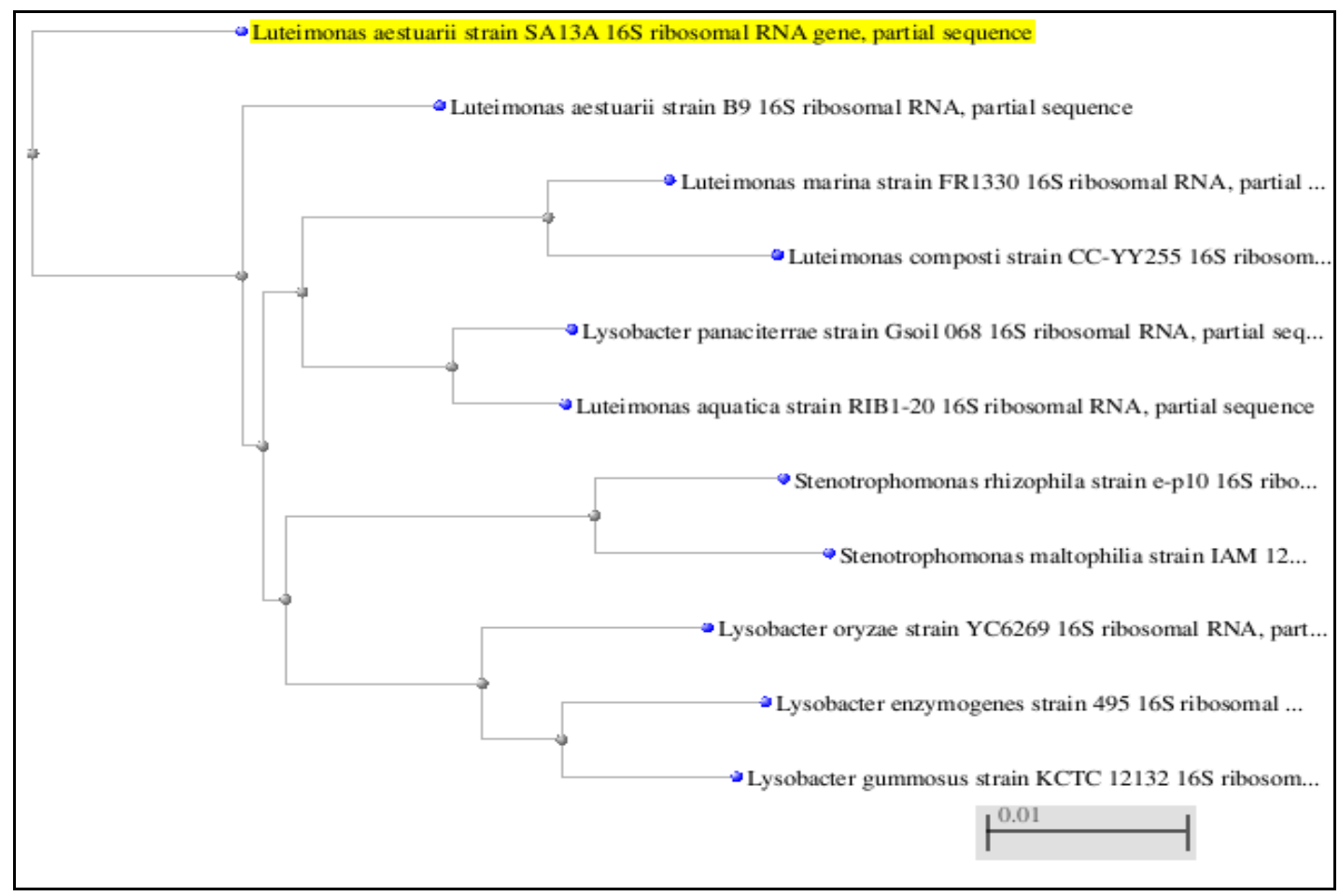


Fig.2 Growth curve of SA13A in absence and presence of $\mathrm{Cr}$ (VI) (Conc. $100 \mathrm{mg} \mathrm{L}^{-1}$ )

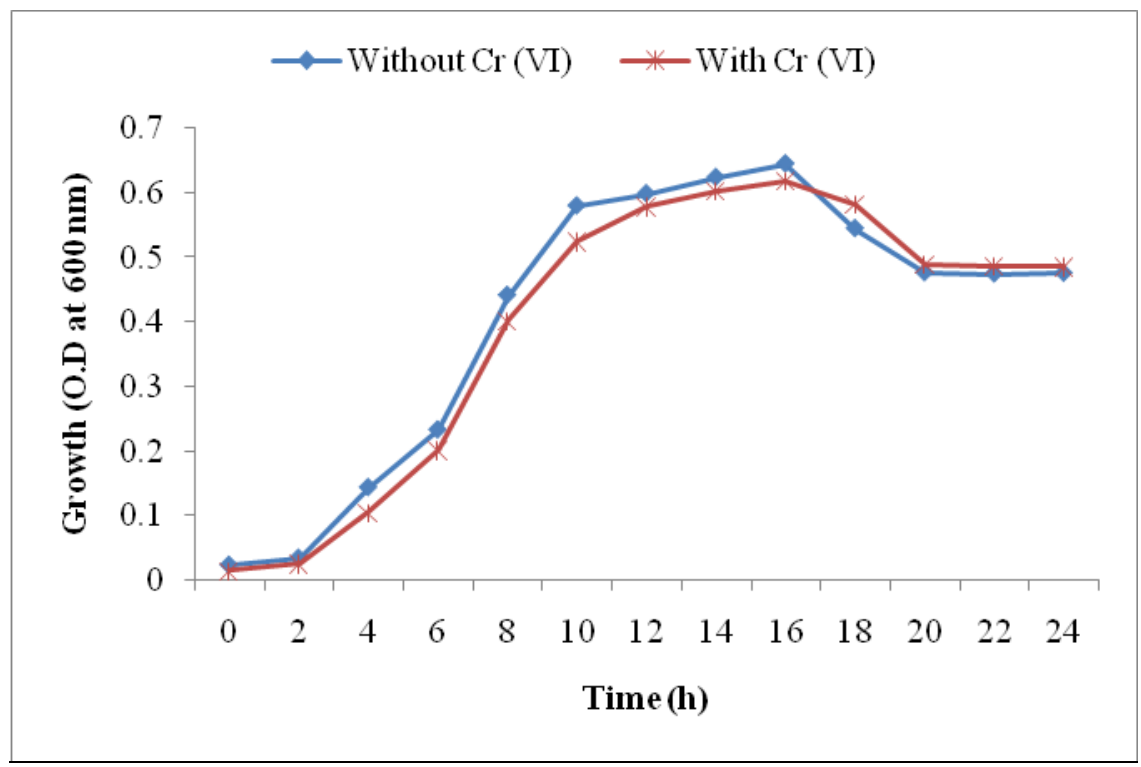

Fig.3 Time course of growth and $\mathrm{Cr}(\mathrm{VI})\left(100 \mathrm{mg} \mathrm{L}^{-1}\right)$ reduction by isolate SA13A

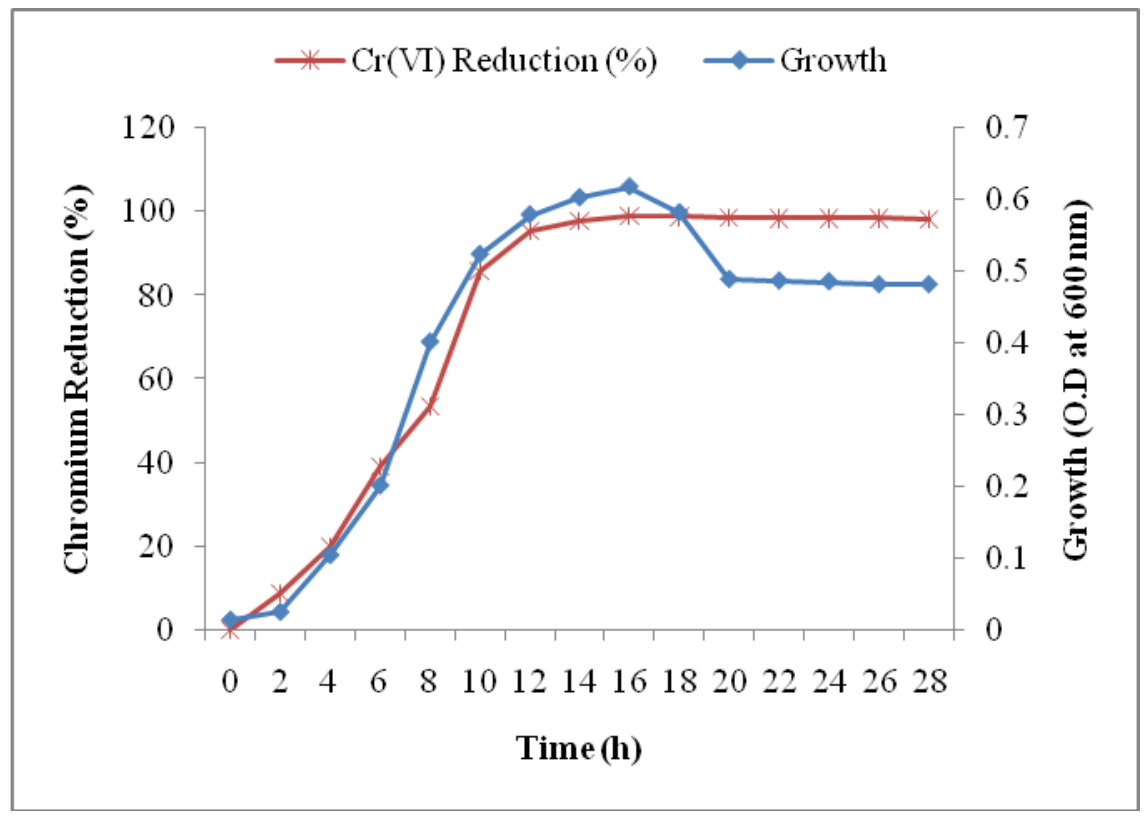


Fig.4 Effect of temperature on $\mathrm{Cr}(\mathrm{VI})$ reduction (Conc. $100 \mathrm{mg} \mathrm{L}^{-1}$ )

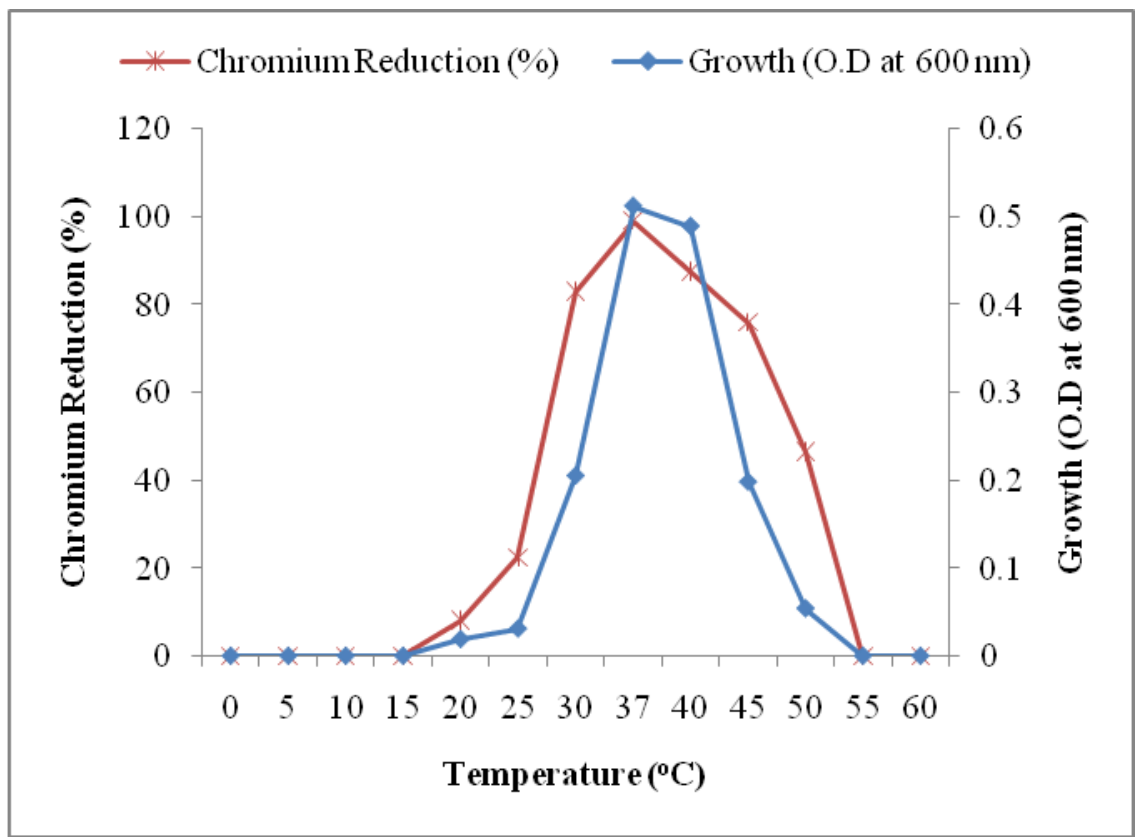

Fig.5 Effect of pH on Cr (VI) reduction (Conc. $100 \mathrm{mg} \mathrm{L}^{-1}$ )

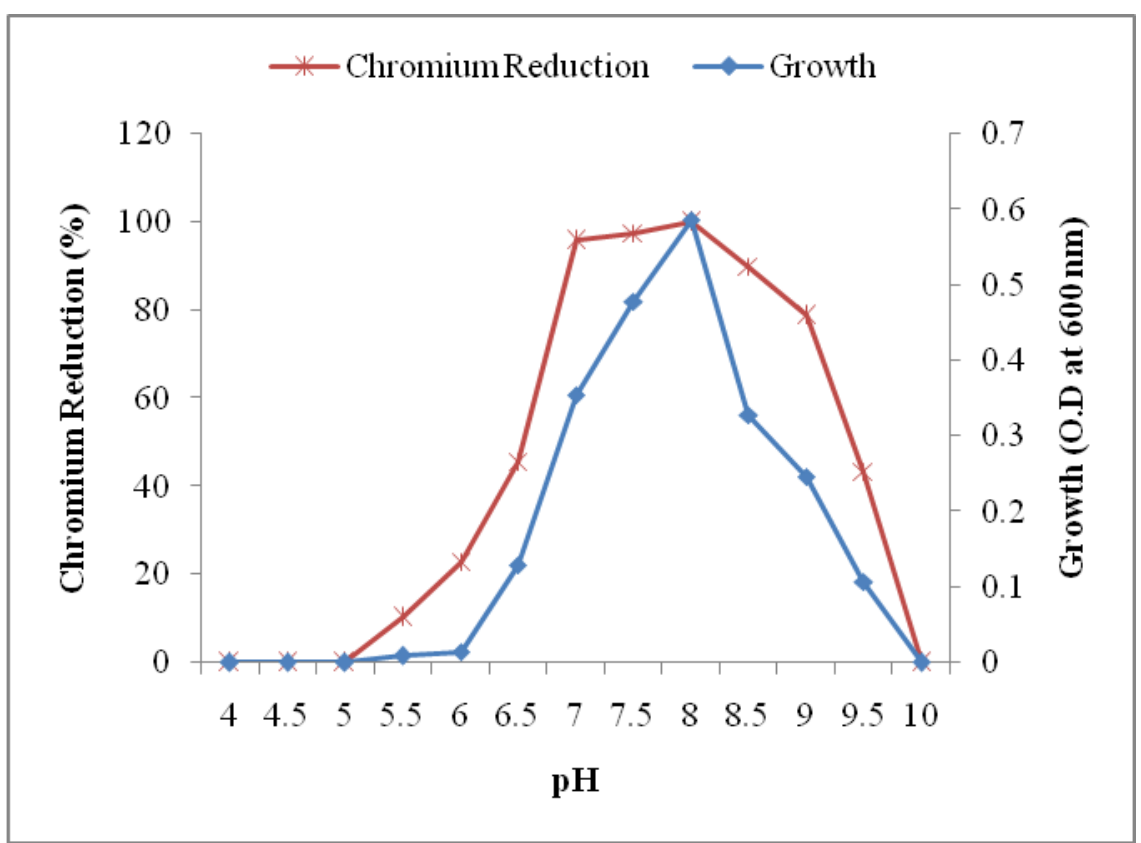

But Liu et al., (2006) reported maximum chromate reduction at $\mathrm{pH}$ 9.0. The change in optimal $\mathrm{pH}$ indicates that $\mathrm{pH}$ modification is important for various cultures to attain the maximum $\mathrm{Cr}(\mathrm{VI})$ reduction during $\mathrm{Cr}(\mathrm{VI})$ detoxification.
In conclusion, industrial workplace is an ideal site for selecting potent metal resistant bacteria since these sites are heavily polluted with heavy metals and other pollutants. Soil contamination via heavy metals is often permanent and may inhibit or even eradicate 
native microbial community. Normally, it is assumed that the heavy metal exposure leads to the establishment of a tolerant microbial population. A gram negative Luteimonas strain SA13A isolated in this study has shown high chromium $\left(100 \mathrm{mg} \mathrm{L} \mathrm{L}^{-1}\right)$ reducing efficiency $(100 \%, 16 \mathrm{~h})$ which is the first compilation of data in conviction with chromate reduction by Luteimonas aestuarii. Moreover, it exhibited resistance against many other heavy metals. Therefore, it may serve as potent novel bacteria for bioremediation applications especially in heavy metal contaminated sites.

\section{Conflict of Interest}

The authors declare that there is no conflict of interests regarding the publication of this article.

\section{References}

Alam, M.Z., Ahmad, S. 2012. Toxic chromate reduction by resistant and sensitive bacteria isolated from tannery effluent contaminated soil. Ann. Microbiol., 62; 113-121.

Aleem, A., Isar, J., Malik, A. 2003. Impact of long-term application of industrial wastewater on the emergence of resistance traits in Azotobacter chroococcum isolated from rhizospheric soil. Bioresour. Technol., 86: 7-13.

Ansari, M.I., Grohmann, E., Malik, A. 2008. Conjugative plasmids in multi-resistant bacterial isolates from Indian soil. $J$. Appl. Microbiol., 104: 1774-1781.

Asatiani, N.V., Abuladze, M.K., Kartvelishvili, T.M., Bakradze, N.G., Sapojnikova, N.A., Tsibakhashvili, N.Y., Tabatadze, L.V., Lejava, L.V., Asanishvili, L.L., Holman, H.Y. 2004. Effect of chromium (VI) action on Arthrobacter oxydans. Curr. Microbiol., 49: 321-326.
Bopp, L.H., Chakrabarty, A.M., Ehrlich, H.L. 1983. Chromate resistance plasmid in Pseudomonas fluorescens. J. Bacteriol., 155; 1105-1109.

Camargo, F.A.O., Bento, F.M., Okeke, B.C., Frankenberger, W.T. 2003. Chromate reduction by chromium-resistant bacteria isolated from soils contaminated with dichromate. $J$. Environ. Qual., 32: 1228-1233.

Cervantes, C., Campos-Garcia, J., Devars, S., Gutierrez-Corona, F., Loza-Tavera, H., Torres-Guzman, J.C., Moreno-Sanchez, R. 2001. Interactions of chromium with microorganisms and plants. FEMS Microbiol. Rev., 25: 335-347.

Cheung, K.H., Gu, J.D. 2007. Mechanism of hexavalent chromium detoxification by microorganisms and bioremediation application potential: a review. Int. Biodeterior. Biodeg., 59: 8-15.

Costa, M., Klein, C.B. 2006. Toxicity and carcinogenicity of chromium compounds in humans. Crit. Rev. Toxicol., 36: 155-163.

Desai, C., Jain, K., Madamwar, D. 2008. Evaluation of In vitro $\mathrm{Cr}$ (VI) reduction potential in cytosolic extracts of three indigenous Bacillus sp. isolated from $\mathrm{Cr}$ (VI) polluted industrial landfill. Bioresour. Technol., 99: 6059-6069.

Hattori, M., Sakaki, Y. 1986. Dideoxy sequencing method using denatured plasmid templates. Anal. Biochem., 152: 232-238.

Ilias, M., Rafiqullah, I.M., Debnath, B.C., Mannan, K.S.B., Hoq, M.M. 2011. Isolation and characterization of chromium (VI) reducing bacteria from tannery effluents. Indian J. Microbiol., 51: 76-81.

Liu, Y.G., Xu, W.H., Zeng, G.M., Li, X., Gao, H. 2006. Cr (VI) reduction by Bacillus sp. isolated from chromium landfill. Process Biochem., 41: 19811986. 
Masood, F., Malik, A. 2011. Hexavalent Chromium Reduction by Bacillus sp. strain FM1 isolated from heavy-metal contaminated soil. Bull. Environ. Contam. Toxicol., 86: 114-119.

Mondaca, M.A., Gonzalez, C.L., Zaror, C.A. 1998. Isolation, characterization and expression of plasmid encoding chromate resistance in Pseudomonas putida KT2441. Lett. Appl. Microbiol., 26: 367-371.

Okeke, B.C. 2008. Bioremoval of hexavalent chromium from water by a salt tolerant bacterium, Exiguobacterium sp. GS1. J. Ind. Microbiol. Biotechnol., 35: 15711579.

Pal, A., Dutta, S., Paul, A.K. 2005. Reduction of hexavalent chromium by cell-free extract of Bacillus sphaericus AND 303 isolated from serpentine soil. Curr. Microbiol., 51: 327-330.

Patra, R.C., Malik, S., Beer, M., Megharaj, M., Naidu, R. 2010. Molecular characterization of chromium (VI) reducing potential in Gram positive bacteria isolated from contaminated sites. Soil Biol. Biochem., 42: 18571863.

Poopal, A.C., Laxman, R.S. 2009. Studies on biological reduction of chromate by Streptomyces griseus. J. Hazard. Mater., 169: 539-545.

Shen, H., Wang, Y.T. 1993. Characterization of enzymatic reduction of hexavalent chromium by Escherichia coli ATCC 33456. Appl. Environ. Microbiol., 59: 3771-3777.

Stepanauskas, R., Glenn, T.C., Jagoe, C.H., Tuckfield, R.C., Lindell, A.H.,
McArthur, J.V. 2005. Elevated microbial tolerance to metals and antibiotics in metal-contaminated industrial environments. Environ. Sci. Technol., 39: 3671-3678.

Sultan, S., Hasnain, S. 2007. Reduction of toxic hexavalent chromium by Ochrobactrum intermedium strain SDCr-5 stimulated by heavy metals. Bioresour. Technol., 98: 340-344.

Tamura, K., Peterson, D., Peterson, N., Stecher, G., Nei, M., Kumar, S. 2011. MEGA5: Molecular Evolutionary Genetics Analysis using Maximum Likelihood, Evolutionary Distance, and Maximum Parsimony Methods. Mol. Biol. Evol., 28: 2731-2739.

Thacker, U., Parikh, R., Shouche, Y., Madamwar, D. 2006. Hexavalent chromium reduction by Providencia sp. Process Biochem., 41: 332-1337.

Viti, C., Pace, A., Giovanetti, L. 2003. Characterization of $\mathrm{Cr}$ (VI) resistant bacteria isolated from chromiumcontaminated soil by tannery activity. Curr. Microbiol., 46: 1-5.

Wang, P.C., Mori, T., Komori, K., Sasatsu, M., Toda, K., Ohtake, H. 1989. Isolation and characterization of Enterobacter cloacae strain that reduces hexavalent chromium under anaerobic conditions, Appl. Environ. Microbiol., 55: 1665-1669.

Yang, J., He, M., Wang, G. 2009. Removal of toxic chromate using free and immobilized $\mathrm{Cr}$ (VI)-reducing bacterial cells of Intrasporangium sp. Q5-1. W. J. Microbiol. Biotechnol., 25: 15791587.

\section{How to cite this article:}

Ankita and Baljeet Singh Saharan. 2017. Luteimonas aestuarii SA13A as a Novel Chromium Reducing Strain isolated from Tannery Effluent. Int.J.Curr.Microbiol.App.Sci. 6(4): 10141022. doi: https://doi.org/10.20546/ijcmas.2017.604.126 